\title{
PAPERMAKING FIBERS FROM GIANT REED (ARUNDO DONAX L.) BY ADVANCED ECOLOGICALLY FRIENDLY PULPING AND BLEACHING TECHNOLOGIES
}

\author{
Anatoly A. Shatalov * and Helena Pereira \\ The anatomical structure and chemical composition of the stem-wall \\ material of giant reed is considered from the viewpoint of raw material \\ characterization for industrial fiber production. The effect of stem \\ morphology (nodes and internodes) on pulping results and general pulp \\ properties is discussed. The advantages of application of modern \\ organic solvent based (organosolv) pulping technologies to giant reed \\ are shown in comparison with the conventional (kraft) method. The \\ conditions optimization for Ethanol-Alkali pulping (a selected organosolv \\ pulping process) is given, and the chemical kinetics of the principal \\ macromolecular components during ethanol-alkali pulping is described. \\ The bleachability of organosolv pulps by short totally chlorine free (TCF) \\ bleaching sequences using hydrogen peroxide and ozone as the active \\ bleaching chemicals without pulp pre-delignification is examined and \\ compared with kraft pulps. The enzymatic pre-treatment of reed \\ organosolv pulps by commercial xylanase preparation is considered as a \\ possibility toward the improvement of pulp bleachability.
}

Keywords: Arundo donax L.; Giant reed; Non-wood fibers; Organosolv pulping; Totally chlorine free (TCF) bleaching; Biobleaching; Bleach boosting

Contact information: Centro de Estudos Florestais, Universidade Técnica de Lisboa, Instituto Superior de Agronomia, Tapada da Ajuda, 1349-017 Lisboa,Portugal; *Corresponding author: anatoly@isa.utl.pt

\section{INTRODUCTION}

Non-woody plants are an important alternative source of fibers for the pulp and paper industry. The role of agro-fiber biomass is particularly prominent in countries with limited wood resources. In some regions of Asia, Africa and Latin America this is the only source of industrial papermaking fibers (Atchison 1993). The need to prevent the fast global deforestation (particularly in North America) and/or to meet the re-orientation of the West European agriculture towards non-food crops, due to general food overproduction, stimulated a recent renewed interest in agro-fiber plants (Van Dam et al. 1994; Moore 1996). A number of new fiber crops (such as elephant grass and reed canary grass) and traditional long-fiber species (such as flax and hemp) were recently (re)investigated for prospective industrial utilization (Leminen et al. 1996).

A widely distributed, naturally growing perennial rhizomatous grass, giant reed (Arundo donax L.), is a well-known fiber crop, the papermaking potential of which is being intensively reconsidered now. It has specific features, such as an annual harvesting period, high biomass productivity (up to $37 \mathrm{t} \mathrm{year}^{-1} \mathrm{ha}^{-1}$, Vecchiet et al. 1996), ability to be intensively cultivated (Dalianis et al. 1994) and easy adaptability to different climatic 
and soil conditions (Perdue 1958) which make A. donax one of the more promising industrial crops.

The history of $A$. donax application for papermaking started in 1830 , when the first pulps were made by the boiling of stem material in calcium hydroxide (Perdue 1958). The comprehensive study of the pulping and bleaching ability of giant reed using traditional kraft and soda processes and chlorine-based bleaching was carried out between 1930-1950. The pulps were produced with rather low yield, but with satisfactory strength properties and bleachability (Jayme et al. 1948; Bhat and Virmani 1951; Di Felippo 1955).

Recently, the Nile Fiber Group Inc. (Washington, USA) together with Samoa Pacific Cellulose (California, USA) announced a successful commercial pulp run using exclusively A. donax reed (Nile Fiber Group 2002). The totally chlorine free (TCF) bleached kraft pulps were produced from reed growing wild in southern California using existing chemical wood pulping facilities of the Samoa Pacific mill. The new wood-free A. donax pulp is planned to be marketed under the name Samoa Cane.

The environmental and economical concern of pulp and paper manufacture, related to conventional pollutant sulfur- and chlorine-based industrial pulping and bleaching technologies, led to a generation of new approaches with reduced negative ecological impact. The pulping methods based on organic solvents in the reaction solution (organosolv pulping) and the bleaching methods based on non-chlorine oxidative chemicals (TCF bleaching) are the real commercially proved alternatives to traditional technologies (Stockburger 1993; Reeve 1996).

In the present article, the possibilities of papermaking fiber production from $A$. donax using organosolv pulping technologies in combination with TCF bleaching are reported based on our accumulated research experience in this field.

\section{EXPERIMENTAL}

\section{Materials}

The stems of giant reed (A. donax), free of leaves, with origin from Athens, Greece were used in this study. A. donax was cultivated in a university experimental plantation (Agricultural Engineering Department, Agricultural University of Athens), without irrigation, and was harvested with an average stem height of $4 \mathrm{~m}$. For pulping, the stems were manually cut up to the approximate size of industrial chips (or match size - for kinetic and pulping optimization studies) and the moisture content was determined according to TAPPI standards. For chemical analysis a small portion of chips was additionally ground and screened to uniform particle size of 40-60 mesh.

\section{Methods}

Extractives were determined gravimetrically after extraction in a Soxhlet apparatus. Ash and silica (as $\mathrm{SiO}_{2}$ ) were quantified according to TAPPI T15 os 58 and TAPPI T 245 om-94, respectively. Hemicelluloses were extracted from chlorite holocellulose by aqueous alkaline solutions and the insoluble residue was accepted as $\alpha$ cellulose (Browning 1967). Carbohydrate composition was analyzed by GC as alditol- 
acetate derivatives of monosaccharides after Saeman hydrolysis (Saeman et al. 1963). Lignin was determined as Klason and acid-soluble according to T 222 om-88 and UM 250 TAPPI, respectively.

The anatomical structure of the stem-wall material was examined by light microscopy of transverse sections (ca. $17 \mu \mathrm{m}$ thickness, Reichert sliding microtome) and dissociated elements (macerated in acetic acid-hydrogen peroxide solution at $60^{\circ} \mathrm{C}$ for 48 hours), as described elsewhere (Shatalov et al. 2001).

Pulping experiments were carried out in a 7-1 laboratory-scale batch reactor with forced circulation of cooking liquor and automatic time-temperature and pressure control (Shatalov and Pereira 2001). Kinetic studies as well as cooking conditions optimization were performed in $100 \mathrm{ml}$ stainless steel autoclaves rotated in an oil bath, using $10 \mathrm{~g}$ (on oven-dry base) material on each pulping (Shatalov and Pereira 2004a, 2004b). Kappa number of pulps was determined according to TAPPI T $236 \mathrm{~cm}-85$. Pulp viscosity was measured in cupri-ethylenediamine (CED) solution according to SCAN-CM 15:88. Handsheet formation for physical and reflectance test of pulps was performed according to TAPPI T 205 om-88 and TAPPI T 272 om-92, respectively. Papermaking properties of pulp handsheets were examined according to TAPPI T 220 om-88. Pulp optical properties, i.e. ISO brightness and DIN $6167 \mathrm{C} / 2$ yellowness index, were measured with a CM-3630 Spectrophotometer (Minolta).

Hydrogen peroxide bleaching (P-stage) as well as pulp chelating (Q-stage) and alkaline extraction (E-stage) were performed in sealed plastic bags plunged into an agitated water bath with temperature control. Low consistency ozone bleaching (Z-stage) was performed in a 2-1 glass reactor (Fischer), equipped with a power stirrer and connected with a laboratory ozone generator (Fischer 502) (Shatalov and Pereira 2005, 2006a). Enzymatic pulp pre-treatment was carried out in the double-layer plastic bags incubated in a water bath under required temperature (Shatalov and Pereira 2006b).

\section{RESULTS AND DISCUSSION}

\section{Giant Reed as a Raw Material for Fiber Production}

Only the stems of $A$. donax are of interest for economically feasible fiber production on a commercial scale. The stem is morphologically heterogeneous and consists of hollow internodes and solid nodes, composed of nodal diaphragm (i.e., residual fragments of fundamental tissue - the pith) and adjacent transition regions (Fig.1).

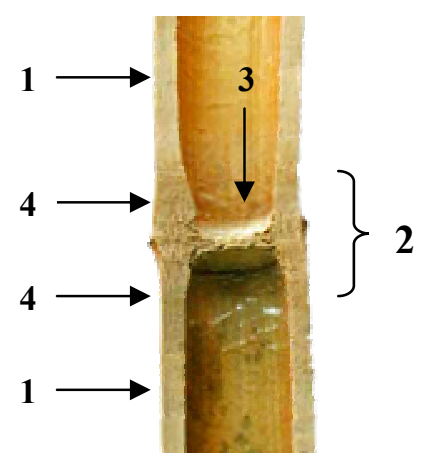

Fig. 1. Longitudinal cross-section of the Arundo donax L. culm: 1 - internode; 2 - node; 3 - nodal diaphragm; 4 transition region (Shatalov and Pereira 2002a). 
These botanically distinct parts can have different response on chemical processing. The anatomical and chemical analysis was therefore performed both with nodes and internodes, and the effect of stem morphology on general pulp properties has been examined using conventional kraft pulping, as a predominant process.

\section{Anatomical structure and fiber morphology}

An anatomical analysis showed similarity in the cellular structure of nodes and internodes (Shatalov and Pereira 2000a; Shatalov et al. 2001). The light microscopy of transverse sections revealed the prevalence of three tissue systems (Fig. 2): epidermal (or cortical parenchyma), fundamental (or ground parenchyma) and vascular (composed of fibro-vascular bundles).
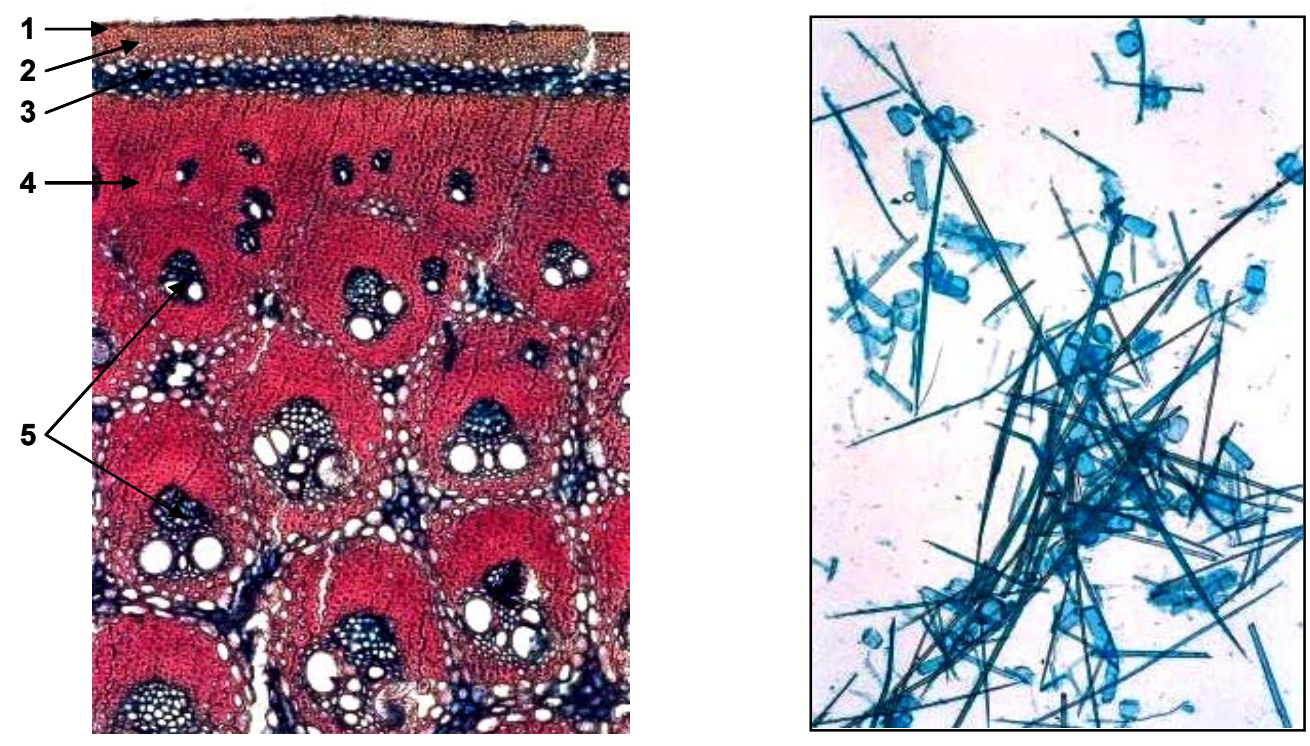

Fig. 2. (left) Transverse section of the internode of $A$. donax culm (100x): 1 - epidermis; 2 strongly sclerified parenchyma cells; 3 - cortical parenchyma; 4 -fibers; 5 - fibro-vascular bundle.

Fig. 3. (right) Macerated sample of the internode of $A$. donax culm (100x) with fibers and parenchyma cells.

The average content of parenchyma in A. donax (57.8\%) differs significantly from wood (7\% and 20\% for soft- and hardwood, respectively, Rydholm 1976) and resembles wheat straw and cornstalks (68\% and 50\%, respectively, Atchison 1993). The proportion of vascular tissue and fibers in A. donax (6.3\% and 35.9\%, respectively) is also different from woods (30\% and 50\% for hardwoods, Rydholm 1976), but close to other grasses, e.g., wheat straw (13.5\% and 37.5\%) and bamboo (11\% and 38\%). Thus, in comparison with woody raw materials, $A$. donax is poorer in fibers and richer in short parenchyma cells.

Biometric analysis of fibers (performed on macerated samples, Fig. 3) revealed some differences in fiber dimensions of nodes and internodes (Shatalov and Pereira 2000a; Shatalov et al. 2001). The fibers from internodes have equal length $(1.2 \mathrm{~mm})$ and smaller diameter (14.6 vs. $16.9 \mu \mathrm{m})$ and cell wall thickness (4.6 vs. $5.3 \mu \mathrm{m})$, suggesting better papermaking properties, as compared to fibers from nodes. The average fiber 
length of A. donax is fairly close to Eucalyptus globulus L. wood (0.7-1.3 mm) and resembles esparto $(1.5 \mathrm{~mm})$, wheat straw $(1.0 \mathrm{~mm})$ and bagasse $(1-1.5 \mathrm{~mm})$. The fiber width of $A$. donax is close to that reported for some eucalypts $(13-19 \mu \mathrm{m})$ and resembles wheat straw $(15 \mu \mathrm{m})$ and cornstalks $(18 \mu \mathrm{m})$ (Atchison 1993). The fiber wall thickness of A. donax does not vary significantly from woods $(2-8 \mu \mathrm{m})$ and is close to wheat straw (4 $\mu \mathrm{m}$ ). Thus, the fiber biometry of $A$. donax (which directly correlates with strength properties of produced paper sheets) is very close to that of such world leaders of wood and non-wood pulp market as eucalypt wood and wheat straw, respectively.

Table 1. Results of Comparative Chemical and Anatomical Analysis of Nodes and Internodes of the A. donax Stem (Shatalov et al. 2001).

\begin{tabular}{|l|c|c|}
\hline & Node & Internode \\
\hline Ash (\% o.d. reed) & 4.77 & 6.14 \\
- silicates & 1.31 & 1.16 \\
\hline Extractives (\% o.d. reed) & 13.04 & 11.16 \\
- dichloromethane & 0.46 & 0.37 \\
- ethanol & 5.88 & 4.18 \\
- hot water & 6.70 & 6.61 \\
\hline Lignin $(\%$ o.d. reed) & 20.92 & 21.31 \\
- Klason & 19.03 & 19.60 \\
- acid-soluble & 1.89 & 1.71 \\
\hline Holocellulose $(\%$ o.d. reed) & 61.21 & 61.41 \\
- $\alpha$-cellulose & 29.18 & 32.93 \\
- hemicelluloses & 32.03 & 28.48 \\
\hline Parenchyma $(\%)$ & 55.8 & 59.8 \\
\hline Fibre $(\%)$ & 37.9 & 33.9 \\
\hline Vascular tissue $(\%)$ & 6.4 & 6.2 \\
\hline Fibre length $(\mathrm{mm})$ & 1.2 & 1.2 \\
\hline Fibre width $(\mu \mathrm{m})$ & 16.9 & 14.6 \\
\hline Fibre wall thickness $(\mu \mathrm{m})$ & 5.3 & 4.6 \\
\hline
\end{tabular}

\section{Chemical composition}

The comparative analysis of chemical composition revealed some differences between nodes and internodes (Shatalov and Pereira 2000a; Shatalov et al. 2001). With close lignin content (ca. 21\%), the nodes are richer in extractives (13.04 vs. $11.16 \%$ ) and hemicelluloses (32.0 vs. $28.5 \%)$ and poorer in cellulose (29.2 vs. $32.9 \%)$, as compared with internodes. Generally, the chemical analysis resembled the typical characteristics for other grasses and deviations from wood. Obviously, A. donax contains considerably less lignin and cellulose than woods (24-34\% and 38-50\%, respectively, Rydholm 1976), but is comparable in hemicelluloses. Similar to other grasses, A. donax showed remarkable predominance of pentosans over hexosans ( $96 \%$ vs. $4 \%$ of hemicelluloses) and the prevalence of xylan over other non-cellulosic polysaccharide (ca $90 \%$ of total). One other difference from wood was found in the relatively high content of ash and extractives, which is also common for grasses. 


\section{Effect of stem morphology on pulp and paper properties}

Different kraft pulping properties of nodes and internodes were established in accordance to the difference in chemical composition and anatomical structure (Shatalov and Pereira 2002a). The pulps with higher screened yield (44.5 vs. 38.6\%) and lower content of residual lignin (Kappa number 25 vs. 33) were produced from internodes, as compared with nodes. The papermaking properties as well as brightness of unbeaten kraft pulps from internodes were also higher (Table 2). Thus, the internodes are more suitable for pulping and the presence of nodes has an adverse affect on pulp yield and properties.

Table 2. Results of Kraft Pulping and Papermaking Properties of Unbeaten Pulps from Nodes, Internodes and the Whole Stems of $A$. donax L. (Shatalov and Pereira 2002a).

\begin{tabular}{|l|c|c|c|}
\hline & Node & Internode & Whole stem \\
\hline Yield (\% o.d. reed) & 43.0 & 44.7 & 43.8 \\
- Screened yield & 38.6 & 44.5 & 42.1 \\
- Rejects & 4.4 & 0.2 & 1.7 \\
\hline Klason lignin (\% o.d. reed) & 4.2 & 3.2 & 3.3 \\
\hline Kappa number & 33 & 25 & 26 \\
\hline Viscosity number $\left(\mathrm{ml} \mathrm{g}^{-1}\right)$ & 1054 & 1156 & 1135 \\
\hline Burst index $\left(\mathrm{kPa} \cdot \mathrm{m}^{2} \mathrm{~g}^{-1}\right)$ & 0.2 & 0.7 & 0.5 \\
\hline Tensile index $\left(\mathrm{N} \cdot \mathrm{m} \mathrm{g}^{-1}\right)$ & 5.2 & 25.2 & 17.4 \\
\hline Tear index $\left(\mathrm{mN} \cdot \mathrm{m}^{2} \mathrm{~g}^{-1}\right)$ & 4.4 & 13.3 & 10.5 \\
\hline Brightness $(\% \mathrm{ISO})$ & 21.2 & 23.9 & 22.8 \\
\hline
\end{tabular}

The results for the whole stem pulping (as the more useful option for practical reasons) are similar or somewhat lower than those for internodes, reflecting the mass proportion of nodes and internodes in the stem.

\section{Organosolv Pulping}

\section{Comparison of different organosolv technologies}

Four different acid- and alkali-based organosolv pulping technologies, which are now under different stages of commercial development, were used to examine the pulping ability of $A$. donax: Alkali-Sulfite-Anthraquinone-Methanol (ASAM), AlkaliAnthraquinone-Methanol (Organocell), Ethanol-Alkali and Peroxyacids (Milox) (Shatalov and Pereira 2000a, 2000b, 2001). The autocatalyzed ethanol pulping of $A$. donax (Repap process) is under investigation now, and the results are not presented here. All methods were applied using standard conditions reported for pulping of similar crops or hardwood (Table 3). Conventional kraft pulp was used as a reference.

The comparative study showed a high accessibility of $A$. donax to organosolv delignification. Bleachable grade pulps with high yield (47-52\% for organosolv vs. 44\% for kraft), ISO brightness (25-37\% ISO for organosolv vs. 23\% ISO for kraft) and intrinsic viscosity (885-1192 $\mathrm{ml} \mathrm{g}^{-1}$ for organosolv vs. $1135 \mathrm{ml} \mathrm{g}^{-1}$ for kraft), good mechanical properties and low content of residual lignin were produced (Table 4). The results of Ethanol-Alkali and ASAM pulping were particularly promising. The properties 
of these organosolv pulps were superior to kraft pulps and comparable with those of industrial hardwood kraft pulp (e.g. E. globulus). The remarkably high brightness of Ethanol-Alkali and ASAM pulps (36.5\% ISO and 37.1\% ISO, respectively) suggested easy pulp bleachability using short bleaching sequences with reduced chemical charge.

Table 3. Pulping Conditions.

\begin{tabular}{|l|c|c|c|c|c|}
\hline & ASAM & Organocell & \multirow{2}{*}{ Ethanol-Alkali } & \multicolumn{2}{|c|}{ Milox } \\
\cline { 4 - 6 } & & & & Stage 1 & Stage 2 \\
\hline Alkali charge (\% o.d.m.) & - & 20 & 25 & - & - \\
\hline Chemical charge $(\%$ o.d.m.) & 20 & - & - & - & - \\
\hline Active alkali $\left(\%\right.$, as $\left.\mathrm{Na}_{2} \mathrm{O}\right)$ & - & - & - & - & - \\
\hline Sulfidity $\left(\%\right.$, as $\left.\mathrm{Na}_{2} \mathrm{O}\right)$ & - & - & - & - & - \\
\hline Solvent content $\%$ by vol.) & 30 & 30 & 40 & - & - \\
\hline $\mathrm{AQ}(\%$ o.d.m.) & 0.1 & 0.1 & - & - & - \\
\hline $\begin{array}{l}\text { Formic acid/acetic acid/water } \\
(\% \text { by vol.) }\end{array}$ & - & - & - & $60 / 20 / 20$ & $60 / 20 / 20$ \\
\hline $\mathrm{H}_{2} \mathrm{O}_{2}$ charge (\% o.d.m.) & - & - & - & 3 & - \\
\hline Liquor-to-material ratio $\left(\mathrm{ml} \mathrm{g}^{-1}\right)$ & $5 / 1$ & $5 / 1$ & $5 / 1$ & $4 / 1$ & $8 / 1$ \\
\hline Pulping temperature $\left({ }^{\circ} \mathrm{C}\right)$ & 175 & 170 & 140 & 90 & 100 \\
\hline Pulping time (min) & 100 & 90 & 180 & 180 & 120 \\
\hline
\end{tabular}

Table 4. Results of Organosolv Pulping of $A$. donax as Compared with Kraft.

\begin{tabular}{|c|c|c|c|c|c|}
\hline & ASAM & Organocell & Ethanol-Alkali & Milox & Kraft (ref.) \\
\hline Yield (\% o.d.m.) & 47.7 & 50.2 & 47.4 & 52.4 & 43.8 \\
\hline - Screened & 46.8 & 46.6 & 47.0 & 51.9 & 42.1 \\
\hline Brightness (\% ISO) & 37.1 & 26.5 & 36.5 & 24.9 & 22.8 \\
\hline Viscosity $\left(\mathrm{ml} \mathrm{g}^{-1}\right)$ & 1192 & 885 & 1140 & 1042 & 1135 \\
\hline Kappa number & 22 & 26 & 21 & 30 & 26 \\
\hline Klason lignin (\% o.d.m.) & 2.6 & 2.7 & 2.5 & 3.6 & 3.3 \\
\hline Burst index $\left(\mathrm{kPa} \mathrm{m}^{2} \mathrm{~g}^{-1}\right)$ & 0.9 & 1.0 & 1.7 & 0.6 & 0.5 \\
\hline Tensile index $\left(\mathrm{N} \mathrm{m} \mathrm{g}^{-1}\right)$ & 14.1 & 16.9 & 27.9 & 14.2 & 17.4 \\
\hline Tear index $\left(\mathrm{mN} \mathrm{m}^{2} \mathrm{~g}^{-1}\right)$ & 10.5 & 9.2 & 11.4 & 7.1 & 10.5 \\
\hline
\end{tabular}

Pulp beating using a laboratory PFI mill showed that the strength properties of reed organosolv pulps (particularly of Ethanol-Alkali pulp) can be substantially improved with minimal energy requirements on beating (Shatalov and Pereira 2000b, 2001). The maximal bursting and tensile strength can be easily reached at 1000 PFI rev. (2000 PFI rev. is required for kraft eucalypt pulp to reach the same values, Valente et al. 1991). At the same time, even moderate beating of organosolv reed pulps (up to 2000 PFI rev.) leads to a dramatic increase in drainage resistance to $60-70^{\circ} \mathrm{SR}$, thereby causing serious dewatering problems (Shatalov and Pereira 2001).

\section{Ethanol-enhanced alkaline pulping}

Based on the results of comparative studies on pulping efficiency, the EthanolAlkali pulping (Ethanol-enhanced or Ethanol-reinforced alkaline pulping) was selected as a sulfur-free organosolv process having more potential for A. donax. The influence of process variables on yield and properties of Ethanol-Alkali pulps has been examined to 
identify the optimal pulping conditions and the kinetics of lignin and carbohydrate degradation during Ethanol-Alkali delignification.

Pulping conditions optimization. The effect of such cooking variables as alkali charge (5-35\% on o.d. reed), ethanol content (20-60\% by vol.), liquor-to-reed ratio (5-8 $\mathrm{ml} / \mathrm{g})$, cooking time $(5-240 \mathrm{~min})$ and cooking temperature $\left(130-150^{\circ} \mathrm{C}\right)$ was examined (Shatalov and Pereira 2002b,c; 2004a,b). The alkalinity of the aqueous phase was found to be a controlling factor of Ethanol-Alkali delignification, strongly affecting pulping results. About $82 \%$ of lignin was removed and pulp yield fell to $49 \%$ with a rise in alkali concentration up to $25 \%$. Ethanol addition to alkaline pulping solution improved substantially the selectivity of delignification (through suppression of degradation reactions of carbohydrates and prevention of lignin condensation reactions, Shatalov and Pereira 2002b). With a rise in ethanol content in the reaction mixture from 20 to $60 \%$ (by vol.), the yield of ethanol-alkali pulps increased by about $5 \%$, while the content of residual lignin decreased by $10 \%$. The intensity of these processes was more notable with ethanol content up to $40 \%$. The change of the liquor-to-reed ratio $(\mathrm{L} / \mathrm{S})$ within an economically reasonable range of $5-8 \mathrm{ml} \mathrm{g}^{-1}$ did not reveal any noticeable effect on pulping results, while the subsequent reduction of $\mathrm{L} / \mathrm{S}$ ratio on pulping is undesirable because of an impaired diffusion of chemicals. The presence of ethanol in the alkaline pulping solution allowed using rather low temperatures for delignification. About $90 \%$ of lignin can be removed with 180 min pulping at $140^{\circ} \mathrm{C}$. Under these gentle conditions, the degradation of polysaccharides was reduced to a minimum, providing fairly high values of screened pulp yield of $45-48 \%$.

Kinetics of lignin and polysaccharide degradation. A novel original approach for kinetic description of lignin and polysaccharide degradation during chemical pulping has been developed and applied (Shatalov and Pereira 2004c; 2005a,b,c).

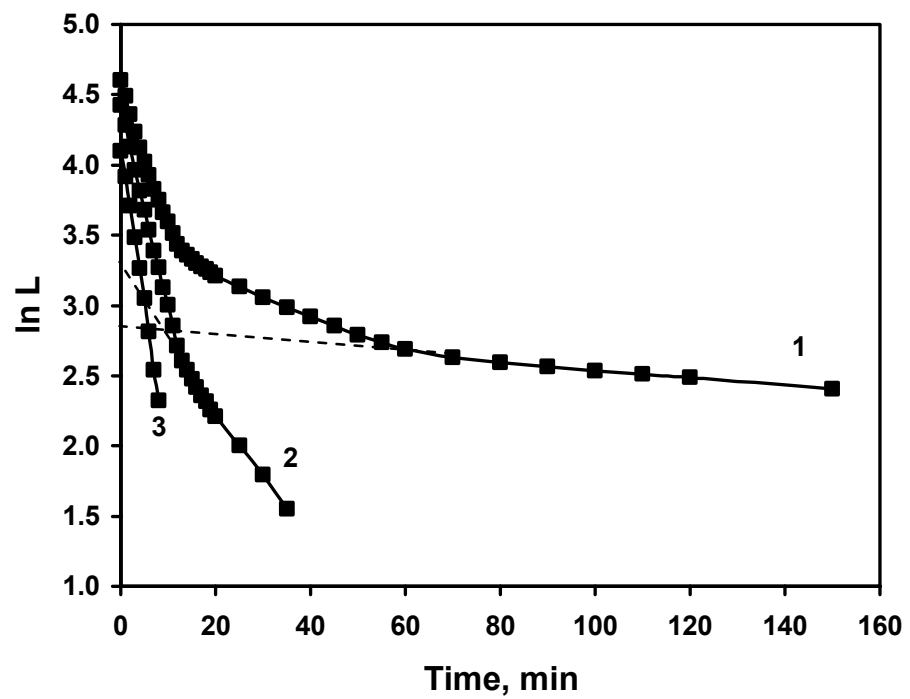

Fig. 4. Kinetic curves of ethanol-alkali delignification of $A$. donax $\left(140^{\circ} \mathrm{C}\right)$ :1-experimental $\operatorname{Ln} L=\operatorname{Ln}\left(L_{1}+L_{2}+L_{3}\right)=\mathrm{f}(t) ; 2$-calculated $\operatorname{Ln}\left(L-L_{3}\right)=\operatorname{Ln}\left(L_{1}+L_{2}\right)=\mathrm{f}(t)$; 3-calculated $\operatorname{Ln}\left(L-L_{3}-L_{2}\right)=\operatorname{Ln} L_{1}=\mathrm{f}(t)$; $L_{1}, L_{2}, L_{3}$ - lignin fractions. 
Based on properties of a multi-component reaction system, the degradation of lignin as well as carbohydrates was considered as a complex of $n$-parallel irreversible first-order reactions with similar final product. The successive elimination from the semilogarithmic anamorphous of kinetic curve of the contributions from the individual polymer structures, or groups of polymer structures with close reactivity (as a kinetically homogeneous system) allowed estimating accurately the kinetic heterogeneity of delignification and quantifying the lignin or carbohydrate fractions with distinguishable reactivity.

Three lignin fractions of $A$. donax were revealed and quantified in proportions of approximately 61,23 and $16 \%$ (Fig. 4). The proportion of lignin fractions was different from that reported for wood, but close to another crop - wheat straw, where the first more reactive lignin fraction was also found as a major fraction (about 90\%). The values of apparent activation energy were estimated respectively as 64, 89 and $96 \mathrm{~kJ} \mathrm{~mol}^{-1}$, and were generally within the range of those reported for wood kraft and organosolv pulping. The simulation of Ethanol-Alkali delignification using the calculated kinetic parameters showed the high reproducibility of experimental data on lignin removal. The data reproducibility was substantially higher in comparison with that obtained by conventional consecutive kinetic model (sum of square residuals (SQR) 0.0036 vs. 0.0856, Shatalov and Pereira 2005a) (Fig.5).

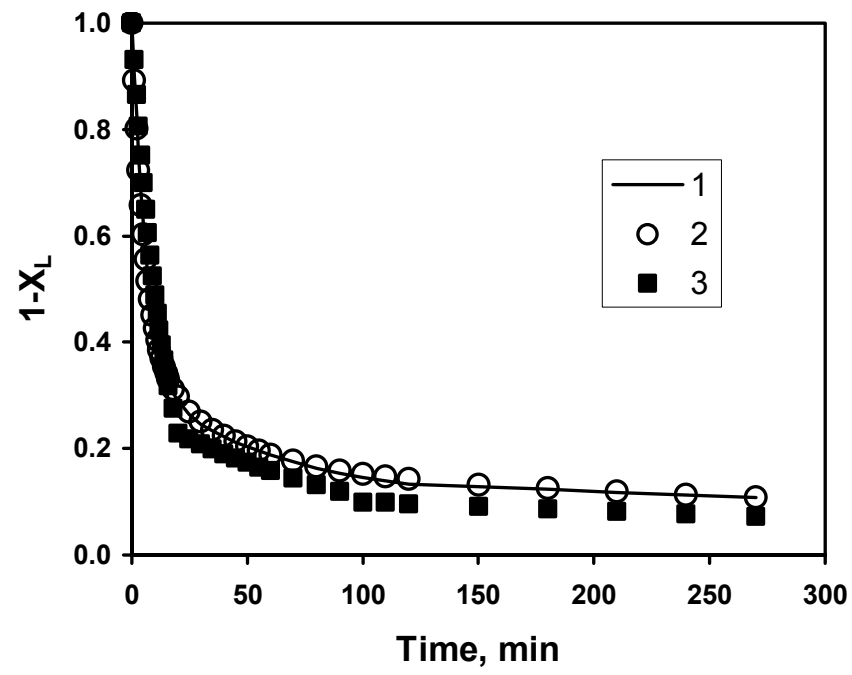

Fig. 5. Data fitting on lignin conversion: 1-experimental kinetic curve; 2-kinetic curve simulated by new model; 3-kinetic curve simulated by traditional model.

The degradation of polysaccharides was accurately described in terms of two kinetically homogeneous fractions. Total polysaccharide losses during Ethanol-Alkali pulping of $A$. donax result mainly from the fast removal of the first more reactive xylan and cellulose fractions (48 and 4\%, respectively, Shatalov and Pereira 2005b). The degradation of the second fractions slowly proceeded through pulping with two to three orders lower rate. The apparent activation energies were estimated as 74.4 and $140.9 \mathrm{~kJ}$ $\mathrm{mol}^{-1}$ - for xylan fractions and 105.2 and $106.5 \mathrm{~kJ} \mathrm{~mol}^{-1}$ - for cellulose fractions. The degradation kinetics of minor A. donax carbohydrates (composed of arabinosyl, 
galactosyl and mannosyl residuals) and uronic acid moieties during ethanol-alkali pulping was also studied (Shatalov and Pereira 2005c).

Hexenuronic acids. The unsaturated 4-deoxy- $\beta$-L-threo-hex-4-enopyranosyluronic acid (hexenuronic acid or HexA) formed from 4-O-methylglucuronic acid (MeGlcA) side groups of heteroxylan by $\beta$-elimination of methanol during alkaline pulping was shown to have harmful effect on subsequent pulp bleaching through the increased consumption of bleaching chemicals, decreased brightness and increased brightness reversion, poor metal removal, and formation of calcium oxalate deposits in the bleaching equipment. It was of special interest to examine the effect of organic solvent (ethanol) addition on the chemical behavior of HexA during alkaline pulping of A. donax. It was shown (Shatalov and Pereira 2003a, 2004d) that in ethanol-alkali reaction medium under pulping conditions about $90 \%$ of the initial uronic acid (UA) moieties of A. donax (composed mainly of MeGlcA side groups attached to heteroxylan) are degraded. At the end of the process, the residual MeGlcA in pulp are $84 \%$ converted to HexA. The maximal detected content of HexA in pulp was $30 \mu \mathrm{mol} \mathrm{g}^{-1}$. No appreciable degradation of HexA during the course of pulping (under the temperature range of $130-150^{\circ} \mathrm{C}$ ) was observed. The overall rate of UA degradation was one order higher than the rate of UA conversion to HexA. The reaction medium alkalinity was found as a controlling factor for UA and HexA stability during pulping. The addition of organic solvent had a similar, but less notable, effect on UA and HexA stability. The kinetics of UA degradation as well as of HexA formation were accurately described in terms of three simultaneous first-order reactions, corresponding to three kinetically homogeneous fractions (Shatalov and Pereira 2003a, 2005c). The degradation of the first two uronic acid fractions (about 50\% of total UA) as well as the formation of the first two hexenuronic acid fractions (about $63 \%$ of total formed HexA) proceeds with similar rates and is completed within the first-third of pulping time. The last (less reactive) HexA fraction is formed with one-order lower rate than the degradation rate of the last UA fraction.

\section{TCF Bleaching of Organosolv Pulps}

Based on the results of the comparative study on organosolv delignification of $A$. donax (Shatalov and Pereira 2001), three alkali-based organosolv pulps, i.e., ASAM, Organocell and Ethanol-Alkali, were chosen for subsequent bleaching experiments. Kraft pulp from A. donax was used as a reference.

\section{Peroxide bleaching}

All of the tested pulps were bleached with a simple three-stage peroxide sequence QPPP (where Q - chelating treatment and P - hydrogen peroxide bleaching stage), without oxygen pre-delignification (Shatalov and Pereira 2003b, 2005d). The conditions applied were identical for each P-stage and are summarized in Table 5. The pulp chelating with EDTA was done before bleaching to remove transition metals. There were some additional chemicals used (Epsom salt and DTPA) to prevent radical-induced degradation of carbohydrates.

The brightness level of ca. 76-78\% ISO was reached for all organosolv pulps (Table 6), irrespective of the starting brightness. It was somewhat higher than that 
reported for oxygen-delignified peroxide bleached soda-AQ reed pulp $(75 \%$ ISO brightness, Basta et al. 2002) and oxygen-delignified QPPP-bleached acetosov pine and eucalypt pulps (67-70\% ISO brightness, Vázquez et al. 2002). The peroxide consumption varied for different pulps and was directly related to starting pulp brightness.

Table 5. Conditions of hydrogen peroxide bleaching.

\begin{tabular}{|c|c|c|}
\hline & Q-stage & P-stage \\
\hline Pulp consistency (\%) & 3 & 10 \\
\hline Temperature $\left({ }^{\circ} \mathrm{C}\right)$ & 70 & 90 \\
\hline Time (min) & 60 & 180 \\
\hline $\mathrm{H}_{2} \mathrm{O}_{2}$ charge (\% o.d. pulp) & - & 3.0 \\
\hline $\mathrm{NaOH}$ charge (\% o.d. pulp) & - & 1.5 \\
\hline EDTA charge (\% o.d. pulp) & 0.3 & - \\
\hline DTPA charge (\% o.d. pulp) & - & 0.2 \\
\hline $\mathrm{MgSO}_{4}$ charge (\% o.d. pulp) ${ }^{*}$ & - & 0.3 \\
\hline $\mathrm{pH}$ initial ${ }^{\star *}$ & 4.5 & - \\
\hline $\mathrm{pH}$ final ${ }^{* * *}$ & - & $10.0-10.40$ \\
\hline
\end{tabular}

Table 6. Properties of peroxide bleached reed organosolv and kraft (ref.) pulps.

\begin{tabular}{|l|c|c|c|c|}
\hline & Ethanol-Alkali & ASAM & Organocell & Kraft (ref.) \\
\hline Yield (\%) & 93.2 & 90.2 & 90.6 & 91.9 \\
\hline $\mathrm{H}_{2} \mathrm{O}_{2}$ consumption (\%) & 60.0 & 68.9 & 82.2 & 74.4 \\
\hline Lignin (\% o.d. pulp) & 2.15 & 1.68 & 1.48 & 1.99 \\
- Klason & 0.78 & 0.72 & 0.50 & 0.89 \\
- Acid-soluble & 1.37 & 0.96 & 0.98 & 1.10 \\
\hline Intrinsic viscosity (ml g $^{-1}$ ) & 1111 & 973 & 788 & 842 \\
\hline Brightness (\% ISO) & 76.4 & 77.0 & 77.6 & 75.4 \\
\hline
\end{tabular}

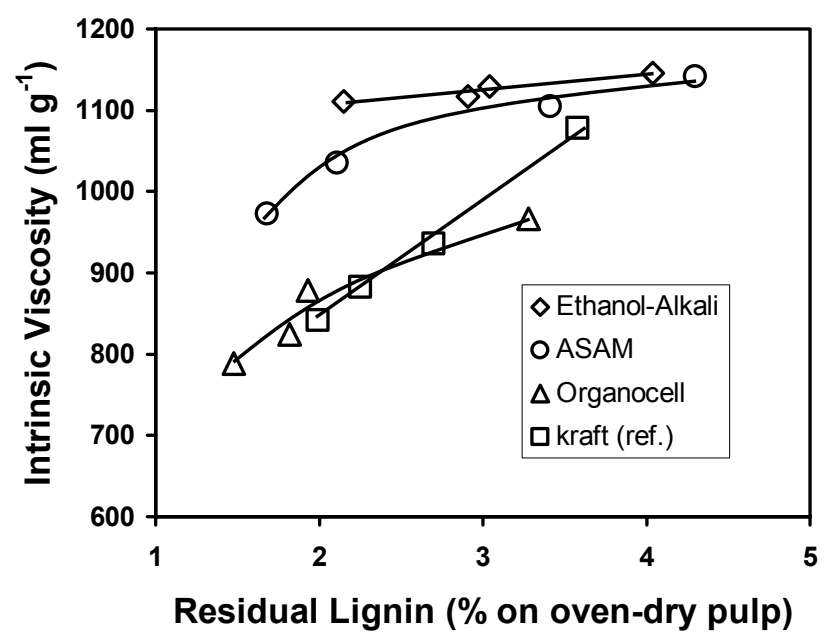

Fig. 6. Selectivity of peroxide bleaching of $A$. donax organosolv pulps (Shatalov and Pereira 2005d). 
All organosolv pulps (particularly Ethanol-Alkali) showed substantially higher bleaching selectivity in comparison with kraft (Fig. 6). The viscosity loss of only 3\% after complete bleaching was noted for Ethanol-Alkali pulp vs. $22 \%$ for kraft. The bleaching efficiency with respect to lignin removal, assumed as a measure of pulp bleachability, was also higher for reed organosolv pulps (Fig. 7). The delignification of ASAM pulp was more intensive (ca. 60\% lignin removal), followed by Ethanol-Alkali and Organocell. The lignin removal from kraft pulp was poorer (ca. 40\%), despite the highest brightness improvement per unit of bleaching chemical consumed (Shatalov and Pereira 2005d). Thus, no correlation between brightening and delignifying effect was observed during peroxide bleaching of $A$. donax pulps.

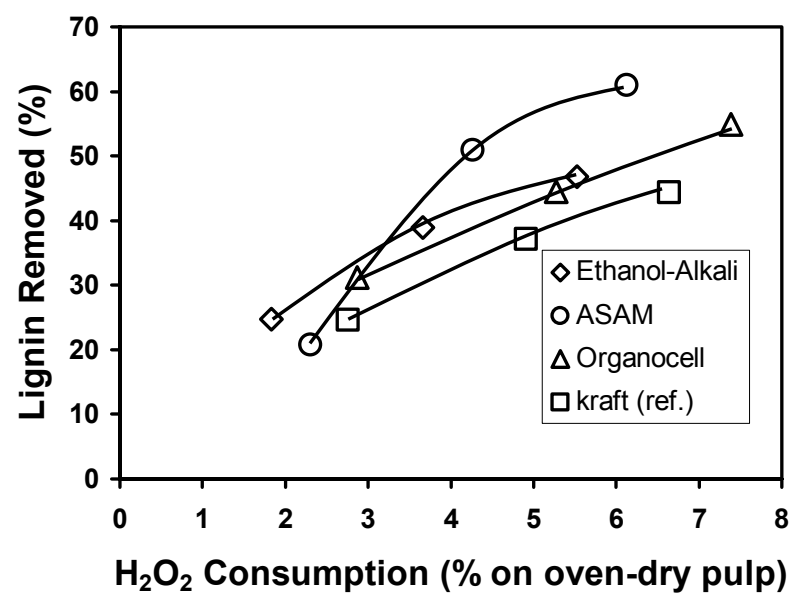

Fig. 7. Delignification efficiency of peroxide bleaching of $A$. donax organosolv pulps (Shatalov and Pereira 2005d).

The papermaking properties of bleached organosolv pulps after PFI beating were found superior (or close) to those of kraft pulp, in contrast to unbleached pulps where the improvement of kraft pulp properties with beating was definitely higher (Shatalov and Pereira 2001).

\section{Ozone-based bleaching}

To consider the possibility of brightness improvement, the introduction of an ozone-stage within a short TCF sequence was studied (Shatalov and Pereira 2005e, 2006a). The ASAM, Organocell and Ethanol-soda pulps were bleached by $A_{Z} E_{R} Q P$ (actually ZEP) bleaching sequence without oxygen pre-bleaching, and compared with conventional kraft pulp (where A - acidic pulp pre-treatment, $Z$ - ozone stage, $E_{R}$ alkaline extraction in the presence of reducing agent, $\mathrm{Q}$ - pulp chelating, $\mathrm{P}$ - hydrogen peroxide stage). The specific bleaching conditions are listed in Table 7.

The introduction of an ozone-stage into the bleaching sequence resulted in an appreciable gain in brightness and degree of delignification in comparison with the threestage peroxide bleaching (Table 8). The brightness was improved by 7.3; 5.8 and 2.0 points, respectively for Ethanol-Alkali, Organocell and ASAM pulps and showed the maximal values of $83.7 \%$ ISO; $83.4 \%$ ISO and $79.4 \%$ ISO, respectively, vs. $79.6 \%$ ISO 
for kraft pulp. The removal of Klason lignin (which directly correlates with kappa number) by $83 \%, 77 \%$ and $69 \%$ was noted respectively for Organocell, Ethanol-Alkali and ASAM pulps, vs. $69 \%$ for kraft pulp. The reduction of ozonated pulps before alkaline extraction allowed limiting carbohydrate degradation with loss in intrinsic viscosity by only $11-18 \%$ for organosolv pulps, vs. $21 \%$ for kraft pulp (Shatalov and Pereira 2006b).

Table 7. Conditions of $A Z E_{R} Q P$ bleaching.

\begin{tabular}{|c|c|c|c|c|c|}
\hline & $\mathrm{A}$ & Z & $\mathrm{E}_{\mathrm{R}}$ & $Q$ & $P$ \\
\hline Pulp consistency (\%) & 3 & 3 & 10 & 3 & 10 \\
\hline Temperature $\left({ }^{\circ} \mathrm{C}\right)$ & 20 & 20 & 60 & 50 & 90 \\
\hline Time (min) & 30 & 20 & 60 & 50 & 90 \\
\hline $\mathrm{O}_{3}(\%$ on oven-dry pulp) & - & 0.8 & - & - & - \\
\hline $\mathrm{H}_{2} \mathrm{O}_{2}$ (\% on oven-dry pulp) & - & - & - & - & 2.5 \\
\hline $\mathrm{NaOH}$ (\% on oven-dry pulp) & - & - & 1.0 & - & 1.5 \\
\hline EDTA (\% on oven-dry pulp) & - & - & - & 0.3 & - \\
\hline DTPA (\% on oven-dry pulp) & - & - & - & - & 0.2 \\
\hline $\mathrm{MgSO}_{4}\left(\%\right.$ on oven-dry pulp) ${ }^{*}$ & - & - & - & - & 0.3 \\
\hline $\mathrm{NaBH}_{4}(\%$ on oven-dry pulp) & - & - & 0.1 & - & - \\
\hline $\mathrm{pH}^{* *}$ & 2.0 & 2.0 & - & 4.5 & - \\
\hline
\end{tabular}

Table 8. Properties of $A Z E_{R} Q P$-bleached organosolv and kraft (ref.) pulps from A. donax.

\begin{tabular}{|l|c|c|c|c|}
\hline & Ethanol-Alkali & ASAM & Organocell & Kraft (ref.) \\
\hline Yield (\%) & 93.4 & 91.0 & 90.9 & 92.1 \\
\hline Lignin (\% o.d. pulp ) & 1.65 & 1.89 & 1.26 & 1.66 \\
- Klason & 0.57 & 0.96 & 0.36 & 0.79 \\
- Acid-soluble & 1.08 & 0.93 & 0.90 & 0.87 \\
\hline Intrinsic viscosity (ml g-1) & 988 & 1009 & 789 & 852 \\
\hline Brightness (\% ISO) & 83.7 & 79.4 & 83.4 & 79.6 \\
\hline Burst index (kPa m $\mathrm{g} \mathrm{g}^{-1}$ ) & 1.32 & 1.30 & 1.27 & 1.11 \\
\hline Tensile index $\left(\mathrm{N} \mathrm{m} \mathrm{g}^{-1}\right)$ & 15.85 & 15.28 & 14.26 & 12.38 \\
\hline Tear index $\left(\mathrm{m} \mathrm{m}^{2} \mathrm{~g}^{-1}\right)$ & 9.16 & 9.02 & 8.54 & 8.84 \\
\hline
\end{tabular}

The pulp bleachability, in terms of improvement in brightness or lignin removal per unit of applied chemicals, was found to be higher for Organocell pulp. The ASAM and Ethanol-Alkali pulps showed the highest bleaching selectivity, expressed by viscosity loss per unit of lignin removed or brightness improved. The development of strength properties of PFI beaten kraft pulp was poorer in comparison with ASAM, but close or somewhat better (as in the case of tearing strength) to Ethanol-Alkali and Organocell pulps. The overall bleaching results of organosolv pulps from $A$. donax were superior to those of kraft (Shatalov and Pereira 2006a).

\section{Enzyme-aided bleaching}

The effect of enzymatic pre-treatment on the bleachability of $A$. donax organosolv pulps has been examined. The ASAM, Organocell and Ethanol-Alkali pulps were treated 
with the commercial xylanase preparation Ecopulp TX-200A (AB Enzymes) and bleached by simple one-stage hydrogen peroxide bleaching. The enzymatic bleach boosting effect was examined and compared with conventional kraft reed pulp (Shatalov and Pereira 2006c, d).

The bleaching effect (i.e., direct brightening and delignification) was already observed during the enzymatic stage and led to a brightness increase by $0.6-1.0 \%$ ISO (more for Ethanol-Akali and Organocell) and lignin removal by $11 \%$ for organosolv pulps vs. $0.7 \%$ ISO and $14 \%$, respectively, for kraft pulp. The xylanase pre-treatment substantially improved the subsequent chemical bleaching of reed organosolv pulps with hydrogen peroxide (Table 9).

Table 9. Properties of enzyme-treated organosolv pulps from $A$. donax after onestage hydrogen peroxide bleaching.

\begin{tabular}{|c|c|c|c|c|}
\hline & ASAM & Ethanol-Alkali & Organocell & Kraft (ref.) \\
\hline Brightness (\% ISO) & $63.4(1.5)^{*}$ & $70.2(2.1)$ & $64.4(2.9)$ & $61.4(2.7)$ \\
\hline Lignin ( $\%$ o.d. pulp) & $2.65(0.22)$ & $2.55(0.29)$ & $1.75(0.30)$ & $1.59(0.33)$ \\
\hline Intrinsic viscosity $\left(\mathrm{ml} \mathrm{g}^{-1}\right)$ & $1144(29)$ & $1140(41)$ & 918(19) & $907(21)$ \\
\hline Peroxide consumption (\%) & $75.4(3.4)$ & $39.7(2.2)$ & $74.3(11.2)$ & $92.7(5.1)$ \\
\hline
\end{tabular}

The gain in brightness by $1.5-2.9 \%$ ISO under reduced consumption of active bleaching chemical by $2.2-11.2 \%$ (as a maximum for Organocell and a minimum for ASAM pulp) was observed. The degree of delignification and intrinsic viscosity of enzyme-treated organosolv pulps increased after peroxide bleaching by $7.7-14.9 \%$ and by 2.1-3.7\%, respectively (Shatalov and Pereira 2006c). Thus, commercial xylanase preparation specifically designed to improve bleachability of industrial wood kraft pulps can be successfully applied to untraditional reed organosolv pulps. This gives the possibility to incorporate enzymatic stage into the TCF bleaching sequences and to increase thereby the final brightness ceiling of bleached pulps. The brightness level of 85$90 \%$ ISO (the fully bleached reed organosolv pulps) can also be achieved by reinforcement of the enzyme-aided TCF bleaching by highly effective catalytic systems of oxidative delignification.

\section{CONCLUSIONS}

A. donax (giant reed) possesses many of the qualities required for an ideal candidate to occupy leading positions on the world non-wood pulp market, and it provides an excellent alternative to wood fibers in meeting the rapidly growing demand for pulp and paper products. The high accessibility of $A$. donax to advanced ecologically friendly pulping and bleaching technologies makes it a particularly attractive and promising fiber source; especially in light of pressure against traditional industrial technologies toward more environmentally sound techniques. 


\section{ACKNOWLEDGMENTS}

The authors gratefully acknowledge the financial support of the Fundação para a Ciência e a Tecnologia (Portugal) within research contract SFRH/BPD/9376/2002.

\section{REFERENCES CITED}

Atchison, J. E. (1993). "The future of non-wood plant fibers in pulp and papermaking." In: Pulp and Paper Manufacture, Vol. 3, Secondary Fibres and Non-Wood Pulping, M. J. Kocurek, ed., TAPPI, CPPA, 4-21.

Basta, J., Holtinger, L., Blom, C., Zhan, H. Y., Fang, H., Li, B. Y., and Li, J. J. (2002). "Overall aspects of $\mathrm{H}_{2} \mathrm{O}_{2}$ bleaching of non-wood fibres," In: Emerging technologies of pulping and papermaking, H. B. Liu, H. Y. Zhan and Y. I. Xie, eds., Guangzhou, China, 377-385.

Bhat, R. V., and Virmani, K. C. (1951). "Indigenous cellulosic raw materials for the production of pulp, paper and board. Part 1. Pulps for writing and printing papers from Arundo donax L.", Indian Forest Leaflet 123, 1-9.

Browning, B. L. (1967). Methods of wood chemistry. Wiley and Sons, New York.

Dalianis C. D., Sooter C. A., and Christou M. G., (1994). "Growing, biomass productivity and energy potential of giant reed (Arundo donax) and elephant grass (Miscanthus sinensis "giganteus")." Proceedings of the 8th European Bioenergy Conference, P. Chartier, A. A. C. M. Beenackers, and G. Grassi, eds., Pergamon, UK, 575-582.

Di Felippo, J. (1955). "Twenty-five years of Argentine industrial experience in the pulping of straw and canes," In: Pulp and Paper Prospects in Latin America, United Nations, FAO, New York.

Jayme, G., Hindenburg, K. G., and Harders-Steinhauser, M. (1948). "Eignungsvergleich verschiedener Einjahrespflanzen als Rohstoff fur Papiersulfatzell-stoffe", Das Papier 2, 45-56.

Leminen, A., Johansson, A., Lindholm, J., Gullichsen, J., and Yilmaz, Y. (1996). Nonwood fibres in papermaking. VTT Research Notes. VTT, Finland. 3-9.

Moore, G. (1996). Nonwood fibre applications in papermaking. Pira International, UK. $1-4$.

Nile Fiber Group (2002). Press release, http://www.nilefiber.com/press release article 1.asp

Perdue, R. E. (1958). "Arundo donax: source of musical reeds and industrial cellulose," Economic Bot. 12, 368-404.

Reeve, D. W. (1996). "Introduction to the principles and practice of pulp bleaching." In: C. W. Dence and D.W. Reeve, eds., Pulp bleaching. Principles and practice. TAPPI Press, Atlanta, (Chapter 1).

Rydholm, S. A. (1976). Pulping processes. Interscience Publishers, NY, Chichester, Brisbane, Toronto. 
Saeman, J. F., Moore, W. E., and Millet, M. A. (1963). In: Methods in Carbohydrate Chemistry, R. L. Whistler, ed., Academic Press, New York, 54-69.

Shatalov A. A., and Pereira H. (2000a). "Arundo donax L. (giant reed) as a source of fibres for paper industry: Perspectives for modern ecologically friendly pulping technologies," Proceedings of the 1st World Conference on Biomass for Energy and Industry, Sevilla, Spain, James \& James Ltd, UK, 2, 1183-1186.

Shatalov A. A., and Pereira H. (2000b). "Organosolv pulping of Arundo donax L. as an alternative to the kraft process for production of high quality non-wood fibres," Proceedings of the 6th European Workshop on Lignocellulosics and Pulp (EWLP), Bordeaux, France, 571-574.

Shatalov, A. A., Quilho, T., and Pereira, H. (2001). "Arundo donax L. reed: New perspectives for pulping and bleaching -1 . Raw material characterization", TAPPI J. 84(1), 1-10.

Shatalov, A.A., and Pereira, H., (2001). "Arundo donax L. reed: New perspectives for pulping and bleaching - 2. Organosolv delignification," TAPPI J. 84(11), 1-12.

Shatalov A. A., and Pereira H. (2002a). "Influence of stem morphology on pulp and paper properties of Arundo donax L. reed," Industrial Crops and Products 15(1): 7783.

Shatalov A. A., and Pereira H. (2002b). "Ethanol-enhanced alkaline pulping of Arundo donax L. reed: influence of solvent on pulp yield and quality," Holzforschung 56(5): 507-512.

Shatalov A. A., and Pereira H. (2002c). "Carbohydrate behaviour of Arundo donax L. in ethanol-alkali medium of variable composition during organosolv delignification," Carbohydrate Polymers 49(3): 331-336.

Shatalov A. A., and Pereira H. (2003a). "Hexenuronic acids in ethanol-alkali pulping," Proceedings of the 12th Int. Symp. on Wood and Pulping Chemistry (ISWPC), Madison, USA, 113-116.

Shatalov A. A., and Pereira H. (2003b). "Influence of organosolv pulping process on TCF bleachability of Arundo Donax L. pulps," Proceedings of the 12th Int. Symp. on Wood and Pulping Chemistry (ISWPC), Madison, USA, 109-112.

Shatalov, A. A., and Pereira, H. (2004a). "Arundo donax L. reed: New perspectives for pulping and bleaching - 3. Ethanol-reinforced alkaline pulping," TAPPI J. 3(2), 2731.

Shatalov A. A., and Pereira H. (2004b). "Papermaking fibres from giant reed (Arundo donax L.) by sulfur-free pulping and chlorine-free bleaching," Proceedings of the 2nd World Conference on Biomass for Energy, Industry and Climate Protection, 10-14 May 2004, Rome, Italy, 1939-1942.

Shatalov A. A., and Pereira H. (2004c). "Improved delignification kinetics of Arundo donax L. as a way to increase the quality of non-wood papermaking fibres," Proceedings of the 2nd World Conference on Biomass for Energy, Industry and Climate Protection, 10-14 May 2004, Rome, Italy, 1974-1977.

Shatalov A. A., and Pereira H. (2004d). "Uronic (hexenuronic) acid profile of ethanolalkali delignification of giant reed Arundo donax L.," Cellulose 11(1): 109-117.

Shatalov, A. A., and Pereira, H. (2005a). "Kinetics of organosolv delignification of fibre crop Arundo donax L.," Industrial Crops and Products 21(2): 203-210. 
Shatalov A. A., and Pereira H. (2005b). "Kinetics of polysaccharide degradation during ethanol-alkali delignification of giant reed - Part 1. Cellulose and xylan," Carbohydrate Polymers 59(4): 435-442.

Shatalov A. A., and Pereira H. (2005c). "Kinetics of polysaccharide degradation during ethanol-alkali delignification of giant reed - Part 2. Minor carbohydrates and uronic acids," Carbohydrate Polymers 61(3): 304-313.

Shatalov A. A., and Pereira H. (2005d). "Arundo donax L. reed: New perspectives for pulping and bleaching - 4. Peroxide bleaching of organosolv pulps," Bioresource Technology 96(8): 865-872.

Shatalov A. A., and Pereira H. (2005e). "Ozone based TCF bleaching of non-wood organosolv pulps", Proceedings, 13th Int. Symp. On Wood Fibre and Pulping Chemistry (ISWFPC), Auckland, New Zealand, 609-613.

Shatalov A. A., and Pereira H. (2006a). "Arundo donax L. reed: New perspectives for pulping and bleaching - 5. Ozone-based TCF bleaching of organosolv pulps," Bioresource Technology, submitted paper.

Shatalov A. A., and Pereira H. (2006b). "Polysaccharide degradation during ozone based TCF bleaching of non-wood organosolv pulps," Carbohydrate Polymers, in press.

Shatalov A. A., and Pereira H. (2006c). "Enzyme-aided TCF bleaching of non-wood organosolv pulps," accepted for the 9th European Workshop on Lignocellulosics and Pulp (EWLP), 20-30 August, 2006, Vienna, Austria.

Shatalov A. A., and Pereira H. (2006d). "“Xylanase pre-treatment of giant reed organosolv pulps: bleach boosting effect", Industrial Crops and Products, submitted paper.

Stockburger, P. (1993). "An overview of near-commercial and commercial solvent-based pulping processes," TAPPI J. 76(6), 71-74.

Valente, C. A., Mendes de Sousa, A. P., and Furtado, F. P. (1991). In: ESTUDOS 3, Colectânia de estudos de I\&D publicados em 1990 e 1991, TECHNOCEL, S.A., Portugal, 37-45.

Van Dam, J. E. G., Van Vilsteren, G. E. T., Zomers, F. H. A., Shannon, W. B., and Hamilton, I. T. (1994). Industrial fibre crops, Agro-Industrial Research Division, EC.

Vázquez, G., Freire, S., González, J., and Antorrena, G., (2002). “Oxygen delignification as a pretreatment for acetosolv pulps bleaching," TAPPI J. 85(2), 1-5.

Vecchiet, M., Jodice, R., and Schenone, G., (1996). "Agronomic research on giant reed (Arundo donax L.). Management system and cultivation of two different provenance," In: Biomass for Energy and the Environment, P. Chartier, G. L. Ferrero, U. M. Henius, S. Hultberg, J. Sachau, M. Wiinblad, eds., Proceedings of the 9th European Bioenergy Conference, 24-27 June 1996, Copenhagen, Denmark. Pergamon, UK. 1, 644-648.

Article submitted: May 23, 2006; Revised version accepted: June 16, 2006; Published July 10, 2006 